Persepsi Santri tentang Moderasi Islam dan Wawasan Kebangsaan

\author{
Rt. Bai Rohimah \\ Fakultas Keguruan dan Ilmu Pendidikan (FKIP) Universitas Sultan Ageng Tirtayasa \\ (UNTIRTA) Serang Banten \\ bairohimah@gmail.com
}

Naskah diterima: 06-04-2019, direvisi: 03-07-2019, disetujui 19-07-2019

\begin{abstract}
This study aims to find out how the perceptions of santri at Tahfidzul Islamic Boarding School in Ar Rahmah's Qur'an on Islamic concepts and national insights, relationship between Islamic insight and insight into santri nationality, And what are the efforts to build Islamic insights and insights into the nationality of santri. Research in scientific papers uses quantitative descriptive analysis, with descriptive analysis method Quantitative. Can be obtained data that the students have a good understanding of Islamic concepts and nationalities, there is a significant relationship between the perceptions of santri about Islamic insights with national insight based on the Spearman Correlation Test of 0.578 and this shows a strong relationship between Islamic insights into the insights nationality.
\end{abstract}

Keywords: moderation, perception, Islamic insight, nationality insights

\begin{abstract}
Abstrak
Penelitian ini bertujuan mengetahui persepsi santri di Pesantren Ar Rahmah terhadap konsep keislaman dan wawasan kebangsaan, hubungan antara wawasan keislaman dan wawasan kebangsaan dan upaya membangun wawasan keislaman dan wawasan kebangsaan santri. Permasalahan dalam penelitian adalah bagaimana persepsi santri terhadap konsep keislaman dan wawasan kebangsaan? hubungan antara wawasan keislaman dan wawasan kebangsaan? Dan bagaimana upaya membangun wawasan keislaman dan wawasan kebangsaan santri? Penelitian dalam karya tulis ilmiah ini menggunakan analisa deskriptif kuantitatif dengan Metode analisis deskriptif kuantitatif. Diperoleh data bahwa santri memiliki pemahaman yang baik tentang konsep keislaman dan kebangsaan. Berdasarkan Uji Korelasi Spearman sebesar 0,578 dan ini menunjukkan terdapat hubungan yang kuat antara wawasan keislaman santri terhadap wawasan kebangsaannya.
\end{abstract}

Kata Kunci: moderasi, persepsi, wawasan keislaman, wawasan kebangsaan

\title{
Pendahuluan
}

Pesantren adalah lembaga pendidikan Islam tertua yang merupakan produk budaya bangsa. Keberadaan pesantren di Indonesia di awali sejak masuknya Islam ke Indonesia dengan mengadopsi sistem pendidikan keagamaan yang sebenarnya telah lama berkembang sebelum kedatangan Islam (Haedari, 2006, p. 28). Pondok pesantren memiliki andil yang sangat besar terhadap perjalanan sejarah bangsa. Pesantren tidak hanya melahirkan tokoh-tokoh nasional yang berpengaruh, tetapi juga telah berhasil membentuk watak yang khas, dimana masyarakat Indonesia yang mayoritas penduduknya beragama 
Islam, dikenal sebagai masyarakat yang akomodatif, penuh tenggang rasa, madani, agamis (religius) dan berkarakter.

Dalam pengamatan Kuntowijoyo, pesantren berperan sebagai tempat bermuaranya kreativitas budaya bagi kehidupan orang Jawa di pedesaan. Bahkan pesantren bisa menjadi basis ekonomi, sosial dan modalitas kultural yang didasarkan pada semangat pemberdayaan (Kuntowijoyo, 1999, p. 18). Pesantren juga memiliki jalinan hubungan struktural dan fungsional dalam masyarakat, sehingga pesantren mempunyai kapasitas kemandirian, baik bagi lembaganya sendiri maupun bagi pemberdayaan masyarakat disekitarnya (Kuntowijoyo, 1993, p. 25).

Keberadaan pesantren sebagai lembaga pendidikan Islam tradisional di tanah Jawa pada periode 1800-1945 tidak bisa dipandang sebelah mata. Pesantren memiliki peran strategis di dalam kehidupan masyarakat. Itulah sebabnya, keberadaan pesantren mendapatkan tempat dan posisi yang utama karena mampu memberikan pengaruh bagi kehidupan sebagian besar masyarakat.

Tercatat dalam sejarah, bahwa ada beberapa pesantren yang telah berusia lama dan turut menyertai sejarah peradaban di Banten hingga saat ini. Sebut saja pesantren Bani Ali Cikaduen, Bani Rusydi An-Nawawi, Al-Iqtishad Cikedal, Jauharotun Naqiyah dan lainlainnya, adalah merupakan pesantren-pesantren salafi yang ada di Banten yang turut mengawal sejarah peradaban Islam di Banten dari dahulu hingga saat ini (Bruinessen, 1999, p. 35).

Peran pesantren diharapkan mampu melindungi masyarakat dari arus gelombang radikalisme, liberalisme dan hal-hal negatif lainnya yang mengancam NKRI, sehingga pesantren diharapkan dapat menjadi lembaga yang mampu mengembangkan dan menanamkan sikap kebangsaan kepada para santrinya.

Berdasarkan latar belakang di atas, peneliti tertarik untuk meneliti bagaimana peran pesantren tersebut, sehingga diharapkan terjawab teka teki mengenai peran pesantren dalam kaitannya dengan Moderasi Islam dan Wawasan Kebangsaan dalam Persepsi Santri, dengan menggunakan hipotesa sebagai berikut :

Ho : Tidak ada hubungan yang signifikan antara persepsi santri mengenai wawasan keislaman dengan wawasan kebangsaan.

Ha : Terdapat hubungan yang signifikan antara persepsi santri mengenai wawasan keislaman dengan wawasan kebangsaan 
Dalam membuktikan hipotesa tersebut diatas, maka selanjutnya peneliti melakukan kegiatan penelitan secara mandiri, agar terjawab rumusan manakah dari kedua hipotesa tersebut yang dapat diterima.

Berdasarkan latar belakang diatas, dapat dirumuskan beberapa permasalahan yang akan diteliti dalam penelitian ini meliputi sebagai berikut : (a) Bagaimana persepsi santri di Pondok Pesantren Puteri Tahfidzul Qur'an Ar-Rahmah terhadap konsep keislaman dan wawasan kebangsaan?; (b) Bagaimana hubungan antara wawasan keislaman dan wawasan kebangsaan santri puteri di Pondok Pesantren Puteri Tahfidzul Qur'an ArRahmah?; (c) Bagaimana upaya-upaya yang dilakukan dalam membangun wawasan keislaman dan wawasan kebangsaan santri di Pondok Pesantren Puteri Tahfidzul Qur'an Ar-Rahmah?

Berdasarkan rumusan masalah diatas, maka penelitian ini bertujuan: (a) Untuk mengetahui persepsi santri di Pondok Pesantren Puteri Tahfidzul Qur'an Ar-Rahmah terhadap konsep keislaman dan wawasan kebangsaan; (b) Untuk mengetahui hubungan wawasan keislaman dan wawasan kebangsaan di kalangan santri puteri Pondok Pesantren Puteri Tahfidzul Qur'an Ar-Rahmah; (c) Untuk mengetahui upaya yang dilakukan dalam membangun wawasan keislaman dan wawasan kebangsaan santri Pondok Pesantren Puteri Tahfidzul Qur'an Ar-Rahmah.

\section{Kajian Teoritik}

\section{Moderasi Islam}

Moderasi dalam Kamus Besar Bahasa Indonesia berarti kecenderungan berada di titik tengah di antara dua buah kutub ekstrim (Nasional, 2016, p. 50). Menurut Hashim Kamali, moderasi merupakan aspek penting dalam Islam, dimana moderasi dalam Islam mengandung banyak ramifikasi dalam berbagai bidang yang menjadi perhatian Islam. Kamali mengungkapkan bahwa moderasi menyangkut kebajikan moral yang relevan, tidak hanya dengan kehidupan individual, tetapi juga integritas dan citra diri komunitas dan bangsa (Kamali, 2015, p. 15).

Moderasi juga kebajikan yang membantu terciptanya harmoni sosial, dan keseimbangan dalam kehidupan dan masalah individual, baik dalam keluarga maupun masyarakat, serta spektrum hubungan antar manusia yang lebih luas.

Istilah moderasi, dan lawan katanya ekstremisme dan radikalisme, sejak beberapa tahun terakhir menjadi sangat populer. Karena begitu pepulernya di hampir semua pidato pemimpin negara, termasuk pidato Raja Salman di gedung MPR RI, juga mengulangi kata- 
kata itu berkali-kali. Tidak luput tentunya hampir di semua pidato kampanye maupun debat capres AS ketika itu selalu menyebut-nyebut kata moderasi dan lawan katanya ekstremisme atau radikalisme (Rahman, 2016, p. 1).

\section{Wawasan Keislaman}

Wawasan secara etimologis berarti hasil mewawas, tinjauan, pandangan dan dapat juga berarti konsepsi atau cara pandang. Sedangkan Keislaman adalah memiliki makna segala sesuatu yang bertalian dengan agama Islam. Jadi wawasan keislaman adalah segenap upaya meningkatkan pemahaman umat terhadap ajaran Islam secara utuh, khususnya aspek tauhid, syari'ah, dan akhlakul karimah serta pengamalannya dalam setiap segi kehidupan untuk mencapai kebahagiaan di dunia dan di akhirat dengan selalu berpegang teguh pada tali Allah serta semangat ukhuwah Islamiyah (Fachrudin, tt, p. 1) .

\section{Wawasan Kebangsaan}

Wawasan kebangsaan lahir ketika bangsa Indonesia berjuang membebaskan diri dari segala bentuk penjajahan, seperti penjajahan oleh Portugis, Belanda, Inggris, dan Jepang. Perjuangan bangsa Indonesia yang waktu itu masih bersifat lokal ternyata tidak membawa hasil, karena belum adanya persatuan dan kesatuan, sedangkan di sisi lain kaum kolonial terus menggunakan politik "devide et impera". Kendati demikian, catatan sejarah perlawanan para pahlawan itu telah membuktikan kepada kita tentang semangat perjuangan bangsa Indonesia yang tidak pernah padam dalam usaha mengusir penjajah dari Nusantara.

Dalam perkembangan berikutnya, muncul kesadaran bahwa perjuangan yang bersifat nasional, yakni perjuangan yang berlandaskan persatuan dan kesatuan dari seluruh bangsa Indonesia akan mempunyai kekuatan yang nyata. Kesadaran tersebut kemudian mendapatkan bentuk dengan lahirnya pergerakan Budi Utomo pada tanggal 20 Mei 1908 yang merupakan tonggak awal sejarah perjuangan bangsa yang bersifat nasional itu, yang kemudian disusul dengan lahirnya gerakan-gerakan kebangsaan di bidang politik, ekonomi/perdagangan, pendidikan, kesenian, pers dan kewanitaan. Tekad perjuangan itu lebih tegas lagi dengan Sumpah Pemuda 28 Oktober 1928 dengan ikrar "Satu Nusa, Satu Bangsa, dan menjunjung tinggi bahasa persatuan bahasa Indonesia”.

Wawasan kebangsaan tersebut kemudian mencapai satu tonggak sejarah, bersatu padu memproklamasikan kemerdekaan pada tanggal 17 Agustus 1945. Dalam perjalanan sejarah itu telah timbul pula gagasan, sikap, dan tekad yang bersumber dari nilai-nilai 
budaya bangsa serta disemangati oleh cita-cita moral rakyat yang luhur. Sikap dan tekad itu adalah pengejawantahan dari satu wawasan kebangsaan (Yoseph, 2017, p. 1).

\section{Persepsi Santri}

Persepsi didefinisikan dengan pandangan, gambaran, atau anggapan. Hal ini disebabkan karena dalam persepsi terdapat tanggapan seseorang mengenai satu hal atau objek. Secara bahasa, persepsi diartikan sebagai suatu proses pengamatan seseorang terhadap lingkungan dengan menggunakan indra-indra yang dimiliki sehingga ia menjadi sadar akan segala sesuatu yang ada dilingkungannya.

Persepsi memiliki sifat subjektif, karena bergantung pada kemampuan dan keadaan dari masing-masing individu, sehingga akan ditafsirkan berbeda oleh individu yang satu dengan yang lain. Dengan demikian persepsi merupakan proses perlakuan individu yaitu pemberian tanggapan, arti, gambaran, atau penginterprestasian terhadap apa yang dilihat, didengar, atau dirasakan oleh indranya dalam bentuk sikap, pendapat, dan tingkah laku atau disebut sebagai prilaku individu (Hariyanto, 2015, p. 25).

Santri adalah sebutan bagi seseorang yang mengikuti pendidikan agama Islam di pesantren. Biasanya mereka menetap di tempat tersebut hingga pendidikannya selesai. Menurut Clifford Greetz, secara geografis golongan santri biasanya berada dalam wilayah di sekitar pesisir pulau Jawa, yang menjadi titik tolak penyebaran Islam yang berasal dari Timur Tengah. Pemahaman mereka terhadap Islam cukup mendalam bahkan dalam pengamalan terhadap syari'at Islam lebih murni. Itu sebabnya banyak muncul pesantren di sepanjang pantura pulau Jawa. Dengan demikian, santri kategorinya adalah orang yang melaksanakan kewajiban agama secara cermat dan teratur (Gretz, 1964, p. 15).

\section{Metode Penelitian}

Penelitian ini merupakan penelitian studi empiris yaitu penelitian yang diadakan untuk mendapatkan bukti atau fakta-fakta secara murni dan sebenarnya tentang gejalagejala atas permasalahan yang timbul (Umar, 1997, p. 14). Adapun jenis penelitian ini adalah penelitian deskriptif dengan pendekatan kuantitatif, yaitu penelitian yang dilakukan untuk menganalisis data dengan cara mendeskripsikan atau menggambarkan data yang telah terkumpul sebagaimana adanya tanpa bermaksud membuat kesimpulan yang berlaku untuk umum atau generalisasi. Untuk pengambilan data, Kami mendapatkannya melalui pertanyaan-pertanyaan dalam angket yang kami bagikan. Adapun sampel penelitian adalah 
Pesantren Tahfidhul Qur'an Ar Rahmah yang berlokasi di daerah Pandeglang merupakan pesantren yang peneliti jadikan sebagai objek penelitian

Berdasarkan data yang diperolah, dengan jumlah responden 70, dan $\alpha=5 \%$, nilai $\mathrm{r}$ tabel sebesar 0,235. Ketentuan valid atau tidaknya suatu pernyataan mengacu pada ketentuan sebagai berikut:

Jika $\mathbf{r}$ hitung > r tabel, pernyataan dinyatakan valid

Jika $\mathbf{r}$ hitung $<\mathbf{r}$ tabel, pernyataan dinyatakan tidak valid

Dari 30 pernyataan yang ada, dengan melihat tabel item total statistik pada kolom corrected item - total correction, semua item memiliki nilai lebih dari 0,235. Ini menandakan bahwa semua pernyataan dinyatakan valid. Setelah uji validitas, maka selanjutnya dilakukan uji reliabilitas. Untuk mengetahui hal tersebut dengan melihat nilai Alpha (lihat pada kolom Cronbach Alpa dalam tabel Reliability Statictics), dalam hal ini sebesar 0,869. Nilai ini dibandingkan dengan nilai konstanta yaitu 0,6. Ketentuan valid atau tidaknya suatu pernyataan mengacu pada ketentuan sebagai berikut:

\section{Jika $\alpha$ hitung $>$ konstanta, pernyataan dinyatakan reliabel}

Jika $\alpha$ hitung < konstanta, pernyataan dinyatakan tidak reliabel

Berdasarkan hasil uji, nilai Alpha sebesar 0,869 sedangkan nilai konstanta sebesar 0,6 sehingga dari 30 pernyataan tersebut dinyatakan reliabel dan dapat diolah lebih lanjut.

\section{Hasil dan Pembahasan}

Berdasarkan hasil penyebaran kuesioner, dapat dijelaskan sebagai berikut:

Persepsi santri terhadap pernyataan: "Tujuan saya belajar di Pondok ini adalah untuk menjadi penghafal Alquran". Dari total responden 70, sebanyak 62 santri menjawab sangat setuju $(88,6 \%)$, dan 8 santri menjawab setuju (11,4\%). Ini menggambarkan bahwa hampir seluruh santri mempersepsikan bahwa tujuan mereka ke pondok untuk menjadi penghafal Al-Quran sesuai dengan tujuan pondok itu didirikan.

Persepsi santri terhadap pernyataan: "Di samping saya menghafal Alquran, Pondok mengajarkan ilmu-ilmu agama yang lainnya sebagai sarana melaksanakan isi Alquran". Dari total responden 70, sebanyak 51 santri menjawab sangat setuju (72,9\%), 8 santri menjawab setuju (25,7\%), dan 1 santri menjawab tidak setuju. Ini menggambarkan bahwa sebagian besar santri mempersepsikan bahwa selain mengikuti program hafalan Al-Quran, mereka juga mengikuti materi pengajian lainnya untuk menunjang pemahaman Al-Quran. 
Persepsi santri terhadap pernyataan: "Keteladan kiai / guru sangat berpengaruh pada perubahan akhlak santri di pondok ini”. Dari total responden 70, sebanyak 58 santri menjawab sangat setuju (82,9\%), 11 santri menjawab setuju (15,7\%), dan 1 santri menjawab sangat tidak setuju. Ini menggambarkan bahwa sebagian besar santri mempersepsikan bahwa akhlak mereka sangat dipengaruhi keteladanan kiyai atau guru.

Persepsi santri terhadap pernyataan: "Kita tidak boleh memaksakan agama Islam kepada pemeluk agama lain". Dari total responden 70, sebanyak 49 santri menjawab sangat setuju (70,0\%), 17 santri menjawab setuju (24,3\%), 3 santri menjawab ragu ragu $(4,3 \%)$ dan 1 santri menjawab sangat tidak setuju (1,4\%). Ini menggambarkan bahwa sebagian besar santri telah mempersepsikan bahwa pemaksaan agama tidak dibolehkan dalam ajaran agama Islam.

Persepsi santri terhadap pernyataan: “Allah menciptakan manusia itu berbedabeda, sehingga kalau terjadi perbedaan pendapat itu wajar”. Dari total responden 70 , sebanyak 45 santri menjawab sangat setuju (64,3\%), 24 santri menjawab setuju $(34,3 \%)$, dan 1 santri menjawab ragu ragu $(1,4 \%)$. Ini menggambarkan bahwa sebagian besar santri mempersepsikan bahwa Allah telah menciptakan makhluknya dalam kondisi yang berbeda-beda.

Persepsi santri terhadap pernyataan: "Bagi saya, manusia yang paling mulia adalah manusia yang paling bertakwa bukan berdasarkan suku dan adat istiadatnya". Dari total responden 70, sebanyak 65 santri menjawab sangat setuju (92,9\%), dan 5 santri menjawab setuju $(7,1 \%)$. Ini menggambarkan bahwa sebagian besar santri mempersepsikan bahwa manusia yang paling mulia adalah manusia yang paling bertakwa.

Persepsi santri terhadap pernyataan: "Saya merasa Pancasila tidak bertentangan dengan ajaran Islam". Dari total responden 70, sebanyak 35 santri menjawab sangat setuju (50,0\%), 16 santri menjawab setuju (22,9\%), 7 santri menjawab ragu-ragu (10,0\%), 5 santri menjawab tidak setuju $(7,1 \%)$, dan 7 santri menjawab sangat tidak setuju $(10,0 \%)$. Ini menggambarkan bahwa sebagian besar santri mempersepsikan bahwa Pancasila tidak bertentangan dengan ajaran Islam.

Persepsi santri terhadap pernyataan: "Saya merasa UUD 1945 tidak bertentangan dengan ajaran Islam”. Dari total responden 70, sebanyak 23 santri menjawab sangat setuju (32,9\%), 28 santri menjawab setuju (40,0\%), 8 santri menjawab ragu-ragu $(11,4 \%)$, 6 santri menjawab tidak setuju $(8,6 \%)$, dan 5 santri menjawab sangat tidak setuju $(7,1 \%)$. 
Ini menggambarkan bahwa sebagian besar santri mempersepsikan bahwa UUD 1945 tidak bertentangan dengan ajaran Islam.

Persepsi santri terhadap pernyataan: "Patuh pada peraturan dan hukum negara adalah bagian dari ajaran agama Islam”. Dari total responden 70, sebanyak 42 santri menjawab sangat setuju (60,0\%), 23 santri menjawab setuju (32,9\%), dan 3 santri menjawab ragu-ragu (7,1\%). Ini menggambarkan bahwa sebagian besar santri mempersepsikan bahwa mematuhi peraturan dan hukum negara adalah bagian dari ajaran agama Islam.

Persepsi santri terhadap pernyataan: "Pemberontakan kepada pemerintah yang sah dalam agama Islam tidak diperbolehkan”. Dari total responden 70, sebanyak 25 santri menjawab sangat setuju (35,7\%), 33 santri menjawab setuju (47,1\%), 10 santri menjawab ragu-ragu (14,3\%), dan 2 santri menjawab tidak setuju (2,9\%). Ini menggambarkan bahwa sebagian besar santri mempersepsikan bahwa agama Islam melarang melakukan pemberontakan kepada pemerintahan yang sah.

Persepsi santri terhadap pernyataan: "Islam melarang kita untuk sembarangan mengkafirkan sesama muslim lainnya". Dari total responden 70, sebanyak 52 santri menjawab sangat setuju (74,3\%), 17 santri menjawab setuju (24,3\%), dan 1 santri menjawab tidak setuju (1,43\%), Ini menggambarkan bahwa sebagian besar santri mempersepsikan bahwa agama Islam melarang kita untuk mudah mengkafirkan sesama muslim lainnya.

Persepsi santri terhadap pernyataan: "Menikah dengan orang yang berbeda suku dan adat istiadat itu tidak masalah, asalkan beragama Islam”. Dari total responden 70, sebanyak 40 santri menjawab sangat setuju (57,1\%), 21 santri menjawab setuju $(30,0 \%), 5$ santri menjawab ragu-ragu $(7,1 \%)$, dan 4 santri menjawab tidak setuju $(5,7 \%)$. Ini menggambarkan bahwa sebagian besar santri mempersepsikan bahwa menikah dengan orang yang berbeda suku dan adat istiadat itu tidak masalah, asalkan beragama Islam.

Persepsi santri terhadap pernyataan: "Pondok mengajarkan agar kita mencintai tanah air Indonesia”. Dari total responden 70, sebanyak 35 santri menjawab sangat setuju (50,0\%), 29 santri menjawab setuju $(41,4 \%)$, dan 6 santri menjawab ragu-ragu $(8,6 \%)$. Ini menggambarkan bahwa sebagian besar santri mempersepsikan bahwa Pondok mengajarkan agar kita mencintai tanah air Indonesia. Ini didukung oleh temuan Peneliti di lapangan, bahwa di pondok tersebut diadakan upacara memperingati hari kemerdekaan Indonesia. 
Persepsi santri terhadap pernyataan: "Bukti santri cinta tanah air, santri ikut merayakan hari kemerdekaan Indonesia”. Dari total responden 70, sebanyak 37 santri menjawab sangat setuju (52,9\%), 31 santri menjawab setuju (44,3\%), dan 2 santri menjawab ragu-ragu (2,9\%). Ini menggambarkan bahwa sebagian besar santri mempersepsikan bahwa mengikuti upacara merayakan hari kemerdekaan Indonesia adalah bagian dari perwujudan cinta tanah air.

Persepsi santri terhadap pernyataan: "Bagi saya, kemerdekaan bangsa Indonesia itu sangat penting sehingga kita dapat melakukan pembangunan”. Dari total responden 70, sebanyak 32 santri menjawab sangat setuju (45,7\%), 35 santri menjawab setuju 50,0\%), 1 santri menjawab ragu-ragu (1,4\%), dan 2 santri menjawab tidak setuju $(2,9 \%)$. Ini menggambarkan bahwa sebagian besar santri mempersepsikan bahwa kemerdekaan bangsa Indonesia itu sangat penting sehingga kita dapat melakukan pembangunan.

Persepsi santri terhadap pernyataan: "Kemerdekaan Indonesia tidak terlepas dari hasil perjuangan umat Islam (kiyai dan santri)". Dari total responden 70, sebanyak 52 santri menjawab sangat setuju (74,3\%), dan 18 santri menjawab setuju (25,7\%). Ini menggambarkan bahwa sebagian besar santri mempersepsikan bahwa kemerdekaan bangsa Indonesia merupakan hasil perjuangan umat Islam (Kiyai dan Santri).

Persepsi santri terhadap pernyataan: "Indonesia merdeka adalah buah perjuangan dengan darah dan air mata sehingga kemerdekaan ini harus dipertahankan dan diisi". Dari total responden 70, sebanyak 52 santri menjawab sangat setuju (74,3\%), 17 santri menjawab setuju (24,3\%), dan 1 santri menjawab ragu-ragu (1,4\%). Ini menggambarkan bahwa sebagian besar santri mempersepsikan bahwa kemerdekaan bangsa Indonesia merupakan buah perjuangan dengan darah dan air mata sehingga kemerdekaan ini harus dipertahankan dan diisi.

Persepsi santri terhadap pernyataan: "Saya bangga menjadi bagian dari bangsa dan rakyat Indonesia" Dari total responden 70, sebanyak 59 santri menjawab sangat setuju (84,3\%), 10 santri menjawab setuju (14,3\%), dan 1 santri menjawab tidak setuju $(1,4 \%)$. Ini menggambarkan bahwa sebagian besar santri mempersepsikan bahwa santri merasa bangga menjadi bagian dari bangsa dan rakyat Indonesia.

Persepsi santri terhadap pernyataan: "Saya akan marah kalau bangsa Indonesia dihina dan dilecehkan oleh bangsa lain" Dari total responden 70, sebanyak 58 santri menjawab sangat setuju (82,9\%), 11 santri menjawab setuju (15,7\%), dan 1 santri 
menjawab ragu-ragu (1,4\%). Ini menggambarkan bahwa sebagian besar santri mempersepsikan akan marah kalau bangsa Indonesia dihina dan dilecehkan oleh bangsa lain.

Persepsi santri terhadap pernyataan: "Saya pernah belajar Pancasila". Dari total responden 70, sebanyak 45 santri menjawab sangat setuju (64,3\%), 24 santri menjawab setuju (34,3\%), dan 1 santri menjawab ragu-ragu (1,4\%). Ini menggambarkan bahwa sebagian besar santri mempersepsikan pernah belajar Pancasila di sekolah.

Persepsi santri terhadap pernyataan: "Saya masih hafal lambang dan sila-sila dalam Pancasila". Dari total responden 70, sebanyak 38 santri menjawab sangat setuju (54,3\%), 18 santri menjawab setuju (25,7\%), dan 13 santri menjawab ragu-ragu $(18,6 \%)$, dan 1 santri menjawab tidak setuju $(1,4 \%)$. Ini menggambarkan bahwa sebagian besar santri masih hafal lambang dan sila-sila dalam Pancasila.

Persepsi santri terhadap pernyataan: "Saya mengerti dan faham apa makna yang terkandung dalam Pancasila". Dari total responden 70, sebanyak 18 santri menjawab sangat setuju (25,7\%), 37 santri menjawab setuju (52,9\%), dan 15 santri menjawab raguragu $(21,4 \%)$. Ini menggambarkan bahwa sebagian besar santri mengerti dan faham apa makna yang terkandung dalam Pancasila.

Persepsi santri terhadap pernyataan: "Saya pernah belajar Undang-Undang Dasar 1945”. Dari total responden 70, sebanyak 39 santri menjawab sangat setuju (55,7\%), 29 santri menjawab setuju (41,4\%), dan 2 santri menjawab ragu-ragu (2,9\%). Ini menggambarkan bahwa sebagian besar santri pernah belajar Undang-Undang Dasar 1945.

Persepsi santri terhadap pernyataan: "Saya hafal teks pembukaan UndangUndang-Undang Dasar 1945”. Dari total responden 70, sebanyak 23 santri menjawab sangat setuju (32,9\%), 31 santri menjawab setuju (44,3\%), dan 16 santri menjawab raguragu $(22,9 \%)$. Ini menggambarkan bahwa sebagian besar santri masih hafal teks pembukaan Undang- Undang-Undang Dasar 1945.

Persepsi santri terhadap pernyataan: "Saya mengerti dan faham isi (batang tubuh) Undang- Undang-Undang Dasar 1945”. Dari total responden 70, sebanyak 13 santri menjawab sangat setuju (18,6\%), 23 santri menjawab setuju (32,9\%), 33 santri menjawab ragu-ragu $(47,1 \%)$, dan 1 santri menjawab tidak setuju $(1,4 \%)$. Ini menggambarkan bahwa sebagian besar santri mengerti dan faham isi (batang tubuh) Undang- Undang-Undang Dasar 1945. 
Persepsi santri terhadap pernyataan: "Indonesia harus bersatu dan hidup berdampingan walaupun bermacam-macam agama, suku, ras, dan bahasa daerah". Dari total responden 70, sebanyak 57 santri menjawab sangat setuju (81,4\%), 12 santri menjawab setuju $(17,1 \%)$, dan 1 santri menjawab tidak setuju (1,4\%). Ini menggambarkan bahwa sebagian besar santri mengerti dan faham tentang pentingnya persatuan walaupun bermacam-macam agama, suku, ras, dan bahasa daerah.

Persepsi santri terhadap pernyataan: "Kita lebih baik hidup damai dan berdampingan dengan sesama manusia yang berbeda agama dibandingkan berperang dan bertikai setiap saat". Dari total responden 70, sebanyak 51 santri menjawab sangat setuju (72,9\%), 16 santri menjawab setuju (22,9\%), dan 3 santri menjawab ragu-ragu (4,3\%). Ini menggambarkan bahwa sebagian besar santri memiliki persepsi lebih baik hidup damai dan berdampingan dengan sesama manusia yang berbeda agama dibandingkan berperang dan bertikai setiap saat.

Persepsi santri terhadap pernyataan: "Saya marah kalau ada teman yang mengejek teman yang lain karena faktor daerah asal”. Dari total responden 70, sebanyak 29 santri menjawab sangat setuju (41,4\%), 31 santri menjawab setuju (44,3\%), 6 santri menjawab ragu-ragu (8,6\%), 3 santri menjawab tidak setuju $(4,3 \%)$, dan 1 santri menjawab sangat tidak setuju $(1,4 \%)$. Ini menggambarkan bahwa sebagian besar santri memiliki persepsi akan marah kalau ada teman yang mengejek teman yang lain karena faktor daerah asal.

Persepsi santri terhadap pernyataan: "Saya marah kalau ada teman yang mengejek teman yang lain karena faktor bahasa daerah asal”. Dari total responden 70, sebanyak 24 santri menjawab sangat setuju (34,3\%), 36 santri menjawab setuju $(51,4 \%), 5$ santri menjawab ragu-ragu (7,1\%), 3 santri menjawab tidak setuju $(4,3 \%)$, dan 2 santri menjawab sangat tidak setuju (2,9\%). Ini menggambarkan bahwa sebagian besar santri memiliki persepsi akan marah kalau ada teman yang mengejek teman yang lain karena faktor bahasa daerah asal.

Persepsi santri terhadap pernyataan: "Warga Negara Indonesia dari Sabang sampai Merauke bagi saya adalah Saudara saya, sesama anak bangsa”. Dari total responden 70, sebanyak 51 santri menjawab sangat setuju (72,9\%), 16 santri menjawab setuju (22,9\%), dan 3 santri menjawab ragu-ragu (4,3\%). Ini menggambarkan bahwa sebagian besar santri memiliki persepsi bahwa Warga Negara Indonesia dari Sabang sampai Merauke adalah bersaudara, sesama anak bangsa. 
Selanjutnya, peneliti melakukan pengujian hipotesis apakah terdapat korelasi (hubungan timbal balik atau sebab akibat antara Variabel X (Wawasan Keislaman ) dengan Variabel Y (Wawasan Kebangsaan). Hubungan ini dihitung secara kuantitatif dengan skala 0 s.d. 1. Pengukuran statistik asosiasi 2 variabel ini disebut dengan koefisien korelasi. Korelasi disebut sempurna jika koefisien korelasi sama dengan 1 dan jika nol berarti sama sekali tidak memiliki hubungan korelasi.

Peneliti telah membuat kategori koefisien korelasi sebagaimana tabel berikut:

\begin{tabular}{|l|l|l|}
\hline \multicolumn{3}{|c|}{ Tabel Kategori Nilai Korelasi } \\
\hline No & Rata-rata Skor & Penafsiran \\
\hline 1 & $0,00-0,20$ & Dapat Dianggap Tidak Ada \\
\hline 2 & $0,21-0,40$ & Ada tetapi Rendah \\
\hline 3 & $0,41-0,70$ & Cukup Kuat \\
\hline 4 & $0,71-0,90$ & Kuat / Tinggi \\
\hline 5 & $0,91-1,00$ & Sangat Kuat / Sangat Tinggi \\
\hline
\end{tabular}

Berdasarkan olah data analisis korelasi dengan menggunakan aplikasi SPSS 24, diperoleh hasil sebagai berikut:

\begin{tabular}{|c|c|c|c|c|}
\hline \multicolumn{5}{|c|}{ Correlations } \\
\hline & & & $\begin{array}{l}\text { Wawasan } \\
\text { Keislaman }\end{array}$ & $\begin{array}{l}\text { Wawasan } \\
\text { Kebangsagan }\end{array}$ \\
\hline \multirow[t]{6}{*}{ Kendall's tau_b } & \multirow[t]{3}{*}{ Wawasan Keislaman } & $\begin{array}{l}\text { Correlation } \\
\text { Coefficient }\end{array}$ & 1,000 & $434^{* *}$ \\
\hline & & Sig. (2-tailed) & & ,000 \\
\hline & & $\mathrm{N}$ & 70 & 70 \\
\hline & \multirow[t]{3}{*}{$\begin{array}{l}\text { Wawasan } \\
\text { Kebangsaan }\end{array}$} & $\begin{array}{l}\text { Correlation } \\
\text { Coefficient }\end{array}$ &, $434^{* *}$ & 1,000 \\
\hline & & Sig. (2-tailed) &, 000 & . \\
\hline & & $\mathrm{N}$ & 70 & 70 \\
\hline \multirow[t]{6}{*}{ Spearman's rho } & \multirow[t]{3}{*}{ Wawasan Keislaman } & $\begin{array}{l}\text { Correlation } \\
\text { Coefficient }\end{array}$ & 1,000 &, $578^{* *}$ \\
\hline & & Sig. (2-tailed) & &, 000 \\
\hline & & $\mathrm{N}$ & 70 & 70 \\
\hline & \multirow[t]{3}{*}{$\begin{array}{l}\text { Wawasan } \\
\text { Kebangsaan }\end{array}$} & $\begin{array}{l}\text { Correlation } \\
\text { Coefficient }\end{array}$ &, $578^{* *}$ & 1,000 \\
\hline & & Sig. (2-tailed) &, 000 & 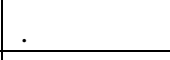 \\
\hline & & $\mathrm{N}$ & 70 & 70 \\
\hline
\end{tabular}




\begin{tabular}{|c|c|c|c|}
\hline \multicolumn{4}{|c|}{ Correlations } \\
\hline & & $\begin{array}{l}\text { Wawasan } \\
\text { Keislaman } \\
\end{array}$ & $\begin{array}{l}\text { Wawasan } \\
\text { Kebangsaan }\end{array}$ \\
\hline \multirow[t]{3}{*}{ Wawasan Keislaman } & Pearson Correlation & 1 &, $653^{* * *}$ \\
\hline & Sig. (2-tailed) & &, 000 \\
\hline & $\mathrm{N}$ & 70 & 70 \\
\hline \multirow[t]{3}{*}{ Wawasan Kebangsaan } & Pearson Correlation &, $653^{* *}$ & 1 \\
\hline & Sig. (2-tailed) &, 000 & \\
\hline & $\mathrm{N}$ & 70 & 70 \\
\hline
\end{tabular}

Dalam mengukur korelasi dua variabel ini, peneliti menggunakan uji korelasi Spearmen dan Kendal. Kedua alat uji ini cocok untuk pengukuran pada statistik non parametrik sehingga bisa menggunakan data ordinal.

Berdasarkan hasil olah data tersebut di atas, kita lakukan uji signifikansi korelasi dengan ketentuan sebagai berikut:

Ho : Tidak ada korelasi atau hubungan yang signifikan antara persepsi santri mengenai wawasan keislaman dengan wawasan kebangsaan (angka korelasi 0)

Ha : Terdapat hubungan yang signifikan antara persepsi santri mengenai wawasan keagamaan terhadap wawasan kebangsaan. (angka korelasi tidak 0)

Dan pengambilan keputusan berdasarkan probabilitas: jika Correlation koeffisien $=$ 0, maka Ho diterima Ha ditolak dan jika Correlation koeffisien > 0, maka Ho ditolak Ha ditolak.

Oleh karena nilai koefisien korelasi (berdasarkan Uji Korelasi Spearman sebesar 0,578) maka kesimpulan hasil uji menunjukkan bahwa Ho ditolak atau Ha diterima. Ini diartikan bahwa terdapat hubungan yang cukup kuat antara Variabel X (Wawasan Keislaman ) dengan Variabel Y (Wawasan Kebangsaan).

Disamping hasil penelitian melalui kuesioner, untuk memperkuat kesimpulan hasil penelitian, peneliti melakukan wawancara dengan Pengasuh Pondok, dan mendapatkan beberapa pandangannya mengenai moderasi Islam dan wawasan kebangsaan.

Menurut beliau, fikrah Islam wașațiyah disebutkan secara tersurat Alquran sebagai 'ummatan wașatan' (QS al Baqarah. 2: 143). Umat seperti inilah yang dapat dan mampu menjadi saksi kebenaran bagi manusia lain. Ummatan wașatan adalah umat yang selalu 
menjaga keseimbangan, tidak terjerumus ke ekstrimisme kiri atau kanan, yang dapat mendorong kepada tindakan kekerasan.

Islam was\}at\}iyyah sebagai paradigma faham keislaman diharapkan bisa mengembalikan keislaman di Indonesia sebagaimana yang dibangun ulama terdahulu, baik dari aspek fikrahnya maupun harakahnya, yaitu keislaman yang mengambil jalan tengah (tawașsutut), berkeseimbangan (tawāzun), lurus dan tegas (I'tidā̄), toleransi (tasāmuḥ), egaliter (musāwaḥ), mengedepankan musyawarah (shüra), berjiwa reformasi (iṣlaḥ), mendahulukan yang prioritas (awlawiyyah), dinamis dan inovatif (tatawwuriyyah) dan berfikir metodologis (manhajiyyah);

Sikap wașatiyyah adalah bersikap tawașsut (jalan tengah) dan i'tidal (bersikap adilseimbang); menyeimbangkan antara iman dan toleransi. Keimanan tanpa toleransi membawa ke arah eksklusivisme dan ekstrimisme, dan sebaliknya, toleransi tanpa keimanan berujung pada kebingungan dan kekacauan. Dengan toleransi, ummatan wașatan berusaha hidup bersama secara damai baik intra maupun antar-umat beragama dan wasatiyah sering diterjemahkan dengan Islam berpaham moderat.

Ketika berbicara mengenai Islam dan negara, menurut pengasuh pondok, sejatinya agama dalam konteks negara mestinya diletakkan sebagai sumber nilai, dan secara fungsional agama mengambil peran tawassut, dalam arti menentukan visi kenegaraannya dengan pendekatan membangun masyarakat Islam (Islam society) dari pada membangun negara Islam (Islam state). Namun tidak berarti kehadiran agama tidak fungsional di hadapan negara. Baginya, Indonesia bukanlah negara agama (teokrasi) dan bukan pula negara sekuler. Negara Indonesia adalah negara modern yang mengakui eksistensi agama dalam kehidupan berbangsa dan bernegara (paradigma simbiosis).

Untuk mewujudkan hal tersebut tentunya kita semua hendaknya dapat menerapkan kaidah Fikrah Islam Wașatiyyah, antara lain:

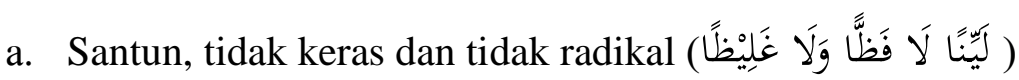

b. Kesukarelaan, tidak memaksa dan tidak mengintimidasi (تَطَوَعِعِا لَا إِكْرَاهَا وَلَا إِجْبَارًا) ,

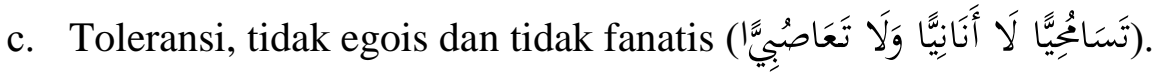

d. Prinsip dalam membangun hubungan antara muslim dan non muslim harus menggunakan kaidah (لَكُمْ دِينُكُمْ وَلِيَ دِينِ), artinya : bagimu agamamu dan bagiku agamaku. Sedangkan prinsip dalam membangun hubungan dengan sesama muslim 
harus menggunakan kaidah (لَنَا مَذْهَبْنَا وَلَكُمْ مَذْهَبْكُمْم), artinya : bagi kami adalah sesuai mazhab kami, dan bagi kamu adalah sesuai mazhab kamu.

e. Saling mencintai, tidak saling bermusuhan dan membenci. Dalam hal ini perlu dikembangkan persaudaraan antar sesama umat Islam (ukhuwah Islāmiyyah), persaudaraan antar sesama warga bangsa (ukhuwwah wataniyyah), dan persaudaraan antar manusia (ukhuwwah insāniyyah);

Salah satu wujud dari watak wasatiyyah dengan pengertian al-wāqi'iyyah (realistis), berpandangan bahwa NKRI dengan Pancasila sebagai dasarnya sebagai sebuah negara yang sah menurut pandangan Islam dan tetap berusaha secara terus menerus melakukan perbaikan sehingga menjadi negara adil makmur berketuhanan Yang Maha Esa.

Selain itu, asas negara dengan Pancasila sebagai titik temu dan UUD 1945 sebagai tatanan kehidupan bangsa. Kedua hal itu kita sebut sebagai ittifáqan akhawiyyah, kesepakatan saudara sebangsa dan setanah air. Indonesia bukanlah negara yang berdasarkan agama (Islam), tetapi Indonesia. adalah negara yang lahir atas kesepakatan seluruh elemen bangsa. Karenanya ada yang menyebutkan bahwa Indonesia sebagai dār-almithāq atau dār al-sulh atau wilayah damai, dār al-'ahdi atau wilayah kesepakatan. Indonesia bukan dār al-Islām (negara Islam);

Sampai saat ini Pesantren Puteri Tahfidhul Qur'an Ar-Rahmah senantiasa mengajarkan prinsip perdamaian. Prinsip ini sejalan dengan misi Islam sebagai "Rahmatan li al-'alamin”, yakni sebagai rahmat bagi seluruh alam, sebagaimana ditegaskan dalam Q.S. Al-Anbiya': 107: “Dan tidaklah Kami mengutus kamu, melainkan untuk (menjadi) rahmat bagi semesta alam".

Prinsip ini juga didasarkan pada Q.S. al-Hujarat: 11: "Wahai manusia, sesungguhnya Aku ciptakan kalian dalam bentuk laki-laki dan perempuan, dan Aku ciptakan kalian dalam bentuk berbangsa dan bersuku-suku agar kalian saling mengenal”.

Saling mengenal dan saling mengakui dalam ayat tersebut menunjukkan perlunya sikap toleran (tasāmuḥ) dari setiap warga negara terhadap keberadaan orang atau kelompok lain, sehingga kelompok lain pun bisa mengekpresikan eksistensi dan hak-hak asasi mereka;

Dengan demikian, Islam tidak membenarkan adanya kekerasan dan apalagi terorisme (irhābiyyah), serta menilainya sebagai tindakan yang tidak manusiawi dan tidak beradab. 
Bahkan jika terjadi konflik dalam masyarakat, Islam mengajarkan untuk menyelesaikannya dengan perdamaian.

\section{Kesimpulan}

1. Persepsi santri pada Pesantren Puteri Tahfidhul Qur'an Ar-Rahmah mengenai wawasan keislaman dan kebangsaan cukup baik, bahkan korelasinya cukup signifikan antara wawasan keislaman dengan wawasan kebangsaan. Hal ini terjadi dikarenakan adanya kesadaran dan keteladan dari Pengasuh Pondok mengenai Islam Moderat/ Islam Wasathiyah.

2. Keunikan Pondok Pesantren Puteri Tahfidhul Qur'an Ar-Rahmah dalam memelihara wawasan kebangsaannya adalah dengan cara mengadakan upacara bendara peringatan Hari Ulang Tahun Kemerdekaan RI. Hal ini cukup unik karena Pondok Pesantren Puteri Tahfidhul Qur'an Ar-Rahmah termasuk dalam kategori pesantren tradisional (salafi) yang letaknya di pedesaan.

3. Adanya upaya dari Pengasuh Pondok untuk mengubah stigma bahwa pesantren adalah sarang teroris dengan membangun dan mengajarkan kepada santrinya tentang paradigma Islam Wasathiyah / Islam Moderat.

\section{Saran}

1. Bagi Pondok Pesantren Puteri Tahfidhul Qur'an Ar-Rahmah, walaupun persepsi santri pada mengenai wawasan keislaman dan kebangsaan cukup baik namun Pengasuh Pondok tetap harus senantiasa mempertahankan kondisi tersebut dengan mengajarkan mengenai Islam Moderat / Islam Wasathiyah.

2. Bagi Pemerintah, paradigma Islam Wasathiyah semestinya menjadi corak faham keagamaan mainstream umat Islam di Indonesia dan dunia pesantren. Hal ini dipandang penting seiring dengan semakin kuatnya indikasi bergesernya gerakan keislaman di negeri ini ke kutub kiri ataupun kutub kanan. Pergeseran ke kutub kiri memunculkan gerakan liberalisme, pluralisme dan sekularisme dalam beragama. Sedangkan pergeseran ke kutub kanan menumbuhkan radikalisme dan fanatisme sempit dalam beragama.

3. Menghadapi revolusi teknologi informasi di Indonesia, di mana semua faham keagamaan bisa diakses dengan mudah dan bebas oleh masyarakat, maka mulai banyak ajaran keagamaan yang awalnya tidak dikenal di Indonesia dan berkembang di negara lain, mulai masuk dan diajarkan di Indonesia, termasuk ajaran keagamaan yang non- 
maistream yang bisa membimbing pemeluknya melakukan tindakan intoleran, keras dan eksklusif. Untuk itu, negara harus tetap mengambil peran dalam menjaga kondisi umat agar tetap wasathiyah.

4. Peran negara dalam pembinaan pondok pesantren antara lain mengawal agar agama menjadi sebagai perekat. Agama akan menjadi perekat jika:

a. Agama mengajarkan agar penganutnya menanamkan pemahaman terhadap teks suci dengan pendekatan kontekstual, universal, dan tidak literal-harfiyah semata;

b. Bersikap hidup inklusif, toleran antara sesama umat beragama, intern mazhab dan aliran dalam satu agama;

c. Menanamkan kemauan untuk mengedepankan nilai-nilai ajaran universal agama;

d. Menanamkan sikap saling menerima keberadaan umat beragama lain dan saling mengerti kebutuhan umat beragama lain;

e. Menanamkan saling percaya dan tidak saling mencurigai antar sesama umat beragama;

f. Mengembangkan forum dialog internal dan antarumat beragama.

\section{Daftar Pustaka}

Bruinessen, M. V. (1999). Kitab Kuning Pesantren dan Tarekat. Bandung: Mizan.

Fachrudin. (tt). Wawasan Keislaman dan KeIndonesiaan. Lampung: Kabepiilampung blog wordpress.com.

Gretz, C. (1964). The Religion Of Java London. London: Free Press Of Glence.

Haedari, A. (2006). Transformasi Pesantren. Jakarta: Lekdis.

Hariyanto. (2015). Pengertian Psikologi Menurut Para Ahli. Belajar Psikologi.com.

https://belajarpsikologi.com/pengertian-persepsi-menurut-ahli/. (2015). Pengertian Persepsi Menurut Para Ahli. Jakarta.

Kamali, M. H. (2015). The Middle Path Of Moderation In Islam:The Quranic Principle Of Wasatiyah. New York: Oxford University Press.

Kuntowijoyo. (1993). Bandung: Mizan.

Kuntowijoyo. (1999). Yogyakarta: Tiara Wacana.

Nasional, D. P. (2016). Kamus Besar Bahasa Indonesia. Jakarta: Grafika.

Rahman, D. A. (2016). Memahami Moderasi Dalam Islam. Jakarta: Republika. co. id. 
Umar, H. (1997). Studi Kelayakan Bisnis. Jakarta: PT Gramedia Pustaka Utama.

Yoseph, S. (2017). Wawasan Kebangsaan. Indonesia. 